\title{
PANDANGAN TEOLOGI REFORMED MENGENAI DOKTRIN PENGUDUSAN DAN RELEVANSINYA PADA MASA KINI
}

\author{
Marde Christian Stenly Mawikere ${ }^{1)^{*}}$ \\ ${ }^{1)}$ Mahasiswa Program Doktor Prodi Teologi Sekolah Tinggi Theologia Jaffray \\ ${ }^{*}$ Penulis korespondensi: mardestenly@gmail.com
}

\begin{abstract}
Abstrak
Artikel ini membahas mengenai pandangan teologi Reformed mengenai Doktrin Pengudusan (Sanctification) dan relevansinya pada masa kini. Teologi Reformed memandang konsep pengudusan sebagai bagian integral dari doktrin keselamatan (soteriologi) yang merupakan karya anugerah Allah yang menjadikan orang pilihan yang kemudian memercayai Yesus Kristus sebagai "orang kudus" (pengudusan definitif) serta berkesinambungan dalam proses kehidupan orang percaya tersebut untuk menghidupi kekudusan dalam kehidupan setiap hari melalui pertumbuhan iman dalam Kristus yang akan berlangsung seumur hidup (pengudusan progresif). Hal ini juga yang menjadi paradoks dalam soteriologi Reformed bahwa pengudusan bersifat monergis (pengudusan definitif) sekaligus sinergis (pengudusan progresif). Dengan demikian, soteriologi Reformed tidak sekadar konsep yang ideal dan filosofis seperti yang tersirat dalam slogan Sola Christo, Sola Gratia, Sola Fide, Sola Scriptura dan Soli Deo Gloria, namun juga bersifat praktis yang melibatkan pengalaman hidup setiap orang percaya dengan Tuhan (Sola Expierientia).

Kata Kunci: Teologi Reformed, soteriologi, Sola Gratia, sanctification, Theatrum Gloriae Dei

This article discusses the view of Reformed Theology concerning the doctrine of sanctification and its relevancy in the world today. Reformed Theology views the concept of sanctification as an integral part of the doctrine of salvation (soteriology) in that it is the work of the grace of God that makes a chosen believer of Jesus Christ, a "holy person" (definitive sanctification) along with the ongoing process in the life of that believer to live in holiness every day through the growth of faith in Christ that will go on for the rest of life (progressive sanctification). This also becomes a paradox in Reformed soteriology in that sanctification is both monergis (definitive sanctification) as well as synergistic (progressive sanctification). As such, Reformed soteriology is not merely an ideal or philosophical concept as is implied in the slogan Sola Christo, Solo Gratia, Sola Fide, Sola Scriptura dan Soli Deo Gloria, however it has a practical nature that involves the everyday experiences of the life of a believer with God (Sola Experientia).
\end{abstract}

Key words: Reformed Theology, soteriology, Sola Gratia, sanctification, Theatrum Gloriae Dei 


\section{Pendahuluan}

Aspek pengudusan atau penyucian (Sanctification) telah menempati domain penting dalam Teologi Sistematika, khususnya doktrin mengenai keselamatan (Soteriologi) dalam kekristenan di samping aspek-aspek lainnya mengenai predestinasi/pemilihan (election), anugerah (grace), kelahiran kembali (regeneration), iman (faith), pembenaran (justification), pengangkatan anak (adoption) dan pemuliaan (glorification). Pengudusan atau penyucian (Sanctification) juga menjadi diskusi dan perdebatan yang penting dalam sejarah gereja dan ragam rumusan teologi, karena sebagian memahami pengudusan sebagai buah dari keselamatan, namun sebagian lagi memahami pengudusan sebagai prasyarat keselamatan. Diskusi dan perdebatan mengenai pengudusan telah menghasilkan ragam pemahaman dan pengajaran dalam gereja. Karena itu, doktrin pengudusan perlu mendapatkan perhatian untuk diteliti, sehingga akan memperoleh pemahaman yang utuh yang pada akhirnya akan terwujud dalam kehidupan dan pelayanan orang-orang percaya pada Tuhan Yesus Kristus.

Studi ini tidak membahas secara eksegetikal mengenai doktrin pengudusan (Sanctification), sekalipun demikian akan tetap memuat dukungan bagian-bagian firman Tuhan terhadap pandangan teologi Reformed mengenai pengudusan. Dengan demikian maka, perspektif teologi Reformed mengenai pengudusan memiliki dasar Alkitab. Studi ini mencoba untuk mengangkat pandangan teologi Reformed mengenai doktrin pengudusan yang diawali dengan meninjau secara singkat perkembangan doktrin pengudusan sebelum dan setelah reformasi. Kemudian dilanjutkan dengan pandangan beberapa teolog Reformed mengenai hakikat pengudusan beserta dengan aspek-aspeknya. Pada akhirnya, penulis akan mencoba merumuskan relevansi doktrin pengudusan pada masa kini.

Studi ini dibangun berdasarkan studi literatur terhadap beberapa buku yang relevan dengan tema pengudusan dalam lingkup pembahasan mengenai Teologi Sistematika, secara khusus Soteriologi. Dalam hal ini penulis memanfaatkan beberapa penelitian/kajian yang telah dilakukan oleh teolog-teolog Reformed.

\section{Tinjauan Mengenai Doktrin Pengudusan Dalam Sejarah}

Sebelum memahami hakikat doktrin pengudusan menurut Teologi Reformed, maka perlu untuk meninjau mengenai perkembangannya dalam sejarah teologi sebelum dan sesudah reformasi. Terdapat tiga persoalan berkaitan dengan aspek-aspek Soteriologi lainnya yang dihadapi oleh gereja berkaitan dengan doktrin pengudusan, yakni: a) 
kaitan antara anugerah Allah dalam pengudusan dengan iman; b) kaitan antara pengudusan dan pembenaran; dan c) tingkat pengudusan dalam hidup sekarang. Para Bapa gereja tidak terlalu banyak berbicara mengenai doktrin pengudusan. ${ }^{2}$ Para Bapa gereja menekankan dan mengajarkan mengenai moralitas dan etika yang ketat yang bergantung pada iman dan perbuatan baik. Pengajaran mengenai baptisan sebagai sarana penghapusan dosa mengindikasikan pemahaman bahwa dosadosa yang dilakukan sebelum baptisan dihapus dan dibersihkan pada waktu pembaptisan, sedangkan dosa-dosa yang dilakukan setelah pembaptisan disucikan melalui pengakuan dosa dan perbuatan baik. Para Bapa gereja yang dipengaruhi dengan ajaran dualisme filsafat Plato kemudian memberikan pengajaran yang keliru mengenai upaya untuk mengatasi dosa dengan cara legalisme, sakramentalisme dan asketisme yang sebenarnya meninggalkan pengudusan yang berhubungan dengan penebusan Kristus. ${ }^{3}$ Doktrin pengudusan dan aspek-aspek soteriologi lainnya mengalami kekeliruan pengajarannya dengan ajaran dari Pelagius, seorang teolog Inggris yang meninggal tahun 419 yang mengajarkan bahwa perbuatan manusialah yang menentukan keselamatannya. Pemahaman ini sangat mempengaruhi teologi gereja Katolik mengenai keselamatan sebagai usaha atau pekerjaan manusia. ${ }^{4}$ Sekalipun demikian gereja zaman reformasi masih memiliki titik terang dengan pengajaran Aurelius Agustinus mengenai keselamatan, termasuk doktrin pengudusan. Agustinus memahami bahwa pengudusan (Sanctification) termasuk dalam pembenaran (Justification). Agustinus memercayai kerusakan total manusia (total depravity) oleh naturnya karena kejatuhan manusia ke dalam dosa. Karena itu, Agustinus menyatakan bahwa pengudusan merupakan suatu tindakan supernatural yang dikerjakan oleh Allah, suatu hidup Ilahi yang diberikan, suatu kekuatan yang dimasukkan dalam diri manusia, yang bekerja secara khusus di dalam gereja dan melalui sakramen-sakramen. ${ }^{5}$ Agustinus cenderung melihat anugerah Allah dalam pengudusan secara metafisik, pengudusan sebagai deposit Allah dalam diri manusia, menurutnya Kristus yang menebus sebagai faktor terpenting dalam

\footnotetext{
${ }^{1}$ Louis Berkhof, Teologi Sistematika Jilid 4 (Surabaya: Momentum, 2001), 257.

${ }^{2} \mathrm{Hal}$ ini karena gereja jaman Bapa-bapa gereja (abad 4-5 M) mempertanyakan natur dari Allah. Apakah Allah yang sejati adalah Allah yang Esa? Bagaimana gereja menjelaskan imannya pada Allah, Yang Esa, yang juga pada saat yang sama, disebut Bapa, Putera dan Roh Kudus? Pergumulan jaman itu adalah pergumulan dengan masalah Trinitas. Lihat Yakub Susabda, Seri Pengantar Teologi Modern I (Jakarta: Lembaga Reformed Injili Indonesia, 1990), 14-16.

${ }^{3}$ Berkhof, 258.

${ }^{4}$ Jan Sihar Aritonang. Garis Besar Sejarah Reformasi (Bandung: Jurnal Info Media, 2007), 6 .

${ }^{5}$ Berkhof, 258.
} 
transformasi kehidupan orang Kristen. Pandangan Agustinus tersebut sangat memengaruhi teologi abad pertengahan (medieval era), ${ }^{6}$ secara khusus dalam tulisan Thomas Aquinas. Sekalipun demikian pembenaran dan pengudusan tidaklah dibedakan dengan jelas. Pembenaran dan pengudusan termasuk dalam infusi anugerah Ilahi, sebagai sesuatu yang substansial ke dalam jiwa manusia. Melalui anugerah ini, jiwa manusia diangkat menuju satu tingkatan baru yang lebih tinggi atau dalam kedudukan yang lebih tinggi, dan jiwa tersebut dimampukan untuk dapat memperoleh tujuan surgawi untuk dapat mengenal, memiliki dan menikmati hubungan dengan Allah. Anugerah tersebut diperoleh melalui jasa-jasa Yesus Kristus yang tidak pernah habis dan diberikan kepada orang percaya melalui sakramen-sakramen. Menurut Thomas Aquinas, apabila dilihat dari sisi Allah maka anugerah yang menguduskan dalam jiwa memastikan adanya remisi bagi dosa asal (original sin), lalu menanamkan kebiasaan yang menetap dari kebenaran batiniah dan membawa potensi untuk berkembang lebih lanjut dan dapat mencapai kesempurnaan. Maka dari hidup yang baru tersebut, muncullah segala kebaikan-kebaikan. Sedangkan dari sisi manusia, karya supernatural dari iman yang bekerja melalui kasih telah mencapai jasa di hadapan Tuhan, dan memastikan akan adanya anugerah yang makin meningkat. Namun pekerjaan seperti itu sangat tidak mungkin tanpa adanya karya anugerah Allah yang terus menerus. ${ }^{7}$ Bagi para teolog abad pertengahan, hasil dari proses tersebut dikenal sebagai pembenaran (yang sebenarnya merupakan hakikat dari pengudusan) serta mempengaruhi gereja Katolik yang kemudian dicantumkan dalam kanon dan keputusan Konsili Trente.

Berkaitan dengan konsep pengudusan sebagai salah satu aspek dalam teologi keselamatan, maka gereja Roma Katolik mengikuti kecenderungan pemikiran teologi gereja abad pertengahan terutama pemikiran Thomas Aquinas di atas. Pada hakikatnya, Aquinas tidak membedakan dengan jelas antara pembenaran (justificatio) dengan penyucian (sanctificatio). Pada hakikatnya pembenaran merupakan penanaman (infusi) anugerah Allah ke dalam jiwa manusia yang olehnya jiwa manusia tersebut diangkat menuju satu tingkatan baru yang lebih tinggi atau dalam kedudukan yang lebih tinggi serta jiwa manusia

\footnotetext{
${ }^{6}$ Gereja abad Pertengahan (medieval era) mempertanyakan akan eksistensi Allah. Apakah betul Allah itu ada? Bagaimana gereja dapat membuktikan keberadaan Allah? Thomas Aquinas (abad $13 \mathrm{M}$ ) bisa disebut sebagai leader gereja yang coba menjawab pertanyaan zamannya. Dengan bukti yang bernuansa filsafat dengan asumsi-asumsi ontologis, teleologis, causalistis, dan sebagainya, ia telah coba membuktikan tentang keberadaan Allah. Lihat Yakub Susabda, Seri Pengantar Teologi Modern I (Jakarta: Lembaga Reformed Injili Indonesia, 1990), 14-16.

${ }^{7}$ Berkhof, 259.
} 
tersebut dimampukan untuk dapat memperoleh tujuan surgawinya untuk dapat mengenal, memiliki, dan menikmati hubungan dengan Allah. Sesungguhnya menurut para teolog abad pertengahan, anugerah diperoleh melalui jasa-jasa Kristus yang tidak pernah habis dan diberikan kepada orang percaya melalui sakramen-sakramen. Apabila dilihat dari sudut pandang Allah, anugerah yang menguduskan dalam jiwa manusia memastikan adanya remisi bagi dosa asal, kemudian menanamkan kebiasaan yang menetap dari kebenaran batiniah, dan membawa potensi untuk berkembang lebih lanjut, bahkan dapat mencapai kesempurnaan. Dari hidup yang baru, kemudian mengeluarkan kebaikan-kebaikan. Adapun perbuatan baik manusia dapat dinetralisasikan atau bahkan dapat dihancurkan oleh dosa-dosa yang mendatangkan maut, namun kesalahan yang telah dilakukan setelah baptisan dapat disingkirkan melalui sakramen ekaristi. Maksudnya kesalahan tersebut merupakan dosa yang ringan atau dapat diampuni melalui sakramen pengakuan dosa dalam hal dosa-dosa yang mendatangkan maut. Sedangkan apabila dipandang dari sudut manusia, karya supernatural dari iman yang bekerja melalui kasih telah mencapai jasa di hadapan Tuhan dan memastikan akan adanya anugerah yang makin meningkat. Sekalipun demikian pekerjaan seperti itu sangat tidak mungkin tanpa adanya karya anugerah Allah yang terus-menerus. Hasil dari keseluruhan proses ini menurut pemahaman gereja Roma Katolik lebih dikenal sebagai pembenaran yakni hal yang menjadikan manusia benar di hadapan Allah dan bukannya pengudusan.

Doktrin pengudusan mengalami perkembangan dengan munculnya Reformasi oleh Martin Luther, Ulrich Zwingly dan Johanes Calvin. ${ }^{9}$ Para

\footnotetext{
${ }^{8}$ Berkhof, 259.

${ }^{9}$ Para reformator seperti Martin Luther, Ulrich Zwingli maupun Johanes Calvin (abad $16 \mathrm{M}$ ) tidak lagi mempertanyakan akan eksistensi Allah yang metaphysical. Bagi mereka gereja membutuhkan pengalaman dengan Allah secara pribadi (yang personal), yang merencana, mempertimbangkan, menetapkan, memilih dan sebagainya. Johanes Calvin, dengan semangat zaman (zeist geist)-nya, mencoba mengembangkan doktrin yang berkisar sekitar "Allah yang personal". Ia mulai dengan basic premise (suatu proposisi dan asumsi dasar) tentang "kedaulatan Allah" (Sovereignty of God). Dari sana, Johanes Calvin menarik suatu logika berpikir, kalau Allah berdaulat berarti, Ia adalah originator dan kreator dari segala yang terjadi. Ia adalah Allah yang punya rencana dan secara aktif terlibat dibelakang setiap gejala-gejala (phenomena). Pasti Ia telah menetapkan (decrees of God) hal-hal yang akan terjadi. Oleh sebab itu tak mungkin ada sesuatu yang terjadi secara kebetulan atau diluar pengetahuan Allah. Dengan demikian Calvin bicara tentang Providensia (pemeliharaan Allah), predestinasi, election, bahkan reprobation (kebinasaan yang sudah ditetapkan bagi mereka yang tidak percaya). Ini adalah manifestasi dari semangat jamannya dimana gereja menggumuli pengenalan mereka akan Allah yang personal, yang pikiran, perasaan, kehendak dan rencanaNya dapat dipahami manusia.Lihat Yakub Susabda, Seri Pengantar Teologi Modern I (Jakarta: Lembaga Reformed Injili Indonesia, 1990), 14-16.
} 
reformator membuat perbedaan yang jelas antara pembenaran dan pengudusan. Mereka mengajarkan bahwa pembenaran adalah suatu tindakan menurut hukum dan anugerah Ilahi yang memungkinkan adanya status yuridis bagi manusia. ${ }^{10}$ Sedangkan pengudusan adalah karya rekreatif yang bersifat moral, yang mengubah sisi batiniah natur manusia. Sekalipun para reformator membuat perbedaan yang jelas antara pembenaran dengan pengudusan, namun mereka juga mereka menekankan adanya kaitan antara keduanya tak tidak terpisahkan. Para reformator sangat menekankan keselamatan sebagai karya kedaulatan dan anugerah Allah saja, karena itu suatu kenyataan bahwa manusia hanya dibenarkan melalui iman saja. Pada sisi lain bagi para reformator, iman yang membenarkan tersebut tidaklah kaku dan statis melainkan dilanjutkan dengan pengudusan, karena Allah mengirimkan Roh AnakNya ke dalam hati umat-Nya setelah mereka dibenarkan, dan Roh itu adalah Roh Kudus yang menguduskan. Para reformator tidak memandang anugerah pengudusan sebagai esensi supernatural yang dimasukkan dalam diri manusia melalui sakramen, melainkan sebagai karya Roh Kudus yang supernatural dan penuh anugerah, pertama kali melalui firman dan kemudian melalui sakramen-sakramen, yang melalui itu Allah melepaskan kita terus-menerus dari kuasa dosa dan memampukan kita untuk melakukan perbuatan baik. Dengan demikian para reformator tidak mencampuradukkan antara pembenaran dengan pengudusan serta tidak memisahkan kaitan antara keduanya, yakni

${ }^{10}$ Martin Luther menemukan kembali doktrin pembenaran dalam Alkitab yang telah lama diselewengkan oleh gereja Roma Katolik melalui pengalaman pribadinya, penelitian akan tulisan Augustinus serta memahami secara baru surat Paulus kepada jemaat di Roma (pasal 1:16-17) yakni mengenai istilah "keadilan/kebenaran Allah" (iustitia Dei) yang adalah istilah kunci dalam ajaran mengenai pembenaran manusia (justificatio). Dalam keadilan-Nya, Allah tidak menghakimi manusia secara adil menurut perbuatannya sehingga ia pasti akan binasa, namun membebaskannya dari hukuman akibat dosa karena jasa Yesus Kristus. Seseorang yang mempercayakan diri dengan iman saja (sola fide) kepada Allah yang penuh anugerah, akan dibenarkan, dianggap dan dinyatakan benar karena kebenaran Kristus dihitung oleh Allah sebagai kebenaran orang percaya. Dengan demikian, hal pembenaran manusia berdosa bukan disebabkan oleh usaha manusia namun anugerah Allah saja sebagai sumber keselamatan manusia. Lihat Christiaan De Jonge, Gereja Mencari Jawab; Kapita Selekta Sejarah Gereja (Jakarta: BPK Gunung Mulia, 2000), 25-26. Johanes Calvin juga menegaskan hal yang sama mengenai doktrin pembenaran yaitu sebagai landasan utama yang harus menjadi dasar agama, karena itu perlu mendapatkan perhatian dan kepedulian yang lebih besar. Karena kecuali seseorang terlebih dahulu memahami posisinya di hadapan Allah, dan hukuman apa yang dijatuhkan-Nya kepadanya, maka orang itu tidak memiliki landasan yang menjadi dasar bagi keselamatannya atau dasar untuk mempersembahkan kesalehan di hadirat Allah. Calvin bahkan menegaskan bahwa doktrin pembenaran adalah engsel utama yang padanya agama berputar. Lihat Anthony A. Hoekema, Diselamatkan Oleh Anugerah (Surabaya: Momentum, 2013), 202. 
penekanan terhadap anugerah Allah yang cuma-cuma dan mengampuni sehingga manusia dibenarkan serta anugerah Allah yang sama yang melakukan pengudusan terhadap orang percaya yang melibatkan kerja sama manusia. ${ }^{11}$

Perkembangan selanjutnya mengenai doktrin pengudusan dalam sejarah setelah reformasi adalah munculnya gerakan Pietisme dan Methodisme yang sangat menekankan akan perlunya persekutuan yang terus-menerus dengan Kristus dan sarana-sarana pengudusan. Dalam gerakan ini terjadi penekanan yang berlebihan terhadap pengudusan yang kemudian merendahkan hakikat pembenaran yang kemudian mengarah kepada pembenaran diri sendiri. John Wesley membedakan antara pembenaran dengan pengudusan, namun ia memisahkan keduanya dalam pengertian kaitan antara keduanya. Wesley memandang pengudusan sebagai pemberian anugerah yang kedua, yang mengikuti yang pertama dari pembenaran karena iman setelah suatu periode tertentu yang singkat maupun panjang. Wesley memang memandang pengudusan sebagai suatu proses, namun ia juga menekankan bahwa orang percaya harus berdoa dan mencari pengudusan yang lengkap, secepatnya melalui suatu tindakan pemisahan (separation) dari Allah. ${ }^{12}$ Karena itu berkaitan dengan doktrin pengudusan dalam gerakan Wesleyan dalam khotbah dan tulisan mereka sering mempergunakan kata "kesempurnaan" (perfection) dan "sempurna" (perfect). Bagi Wesley kesempurnaan alkitabiah adalah "kasih yang sempurna", "seorang Kristen adalah sempurna sejauh dia tidak berbuat dosa", "hati yang bersunat adalah keadaan yang begitu diperbarui dalam gambaran pikiran manusia sehingga menjadi sempurna sama seperti Bapa di Surga adalah sempurna."13 Karena itu bagi gerakan Wesleyan, terdapat kemungkinan bagi orang percaya dalam kehidupan ini untuk mencapai kondisi yang disebut "pengudusan menyeluruh" yang merupakan sinonim dari "kesempurnaan Kristen". Pengudusan menyeluruh merupakan suatu pengalaman yang berbeda dan terjadi setelah pembenaran yang mana seseorang dapat dikuduskan secara menyeluruh sampai bertahun-tahun setelah pembenaran, maka pengudusan menyeluruh disebut sebagai berkat kedua (second blessings). Sebagai suatu berkat kedua, maka pengudusan yang menyeluruh merupakan suatu pengalaman seketika yang diterima dengan iman. Maka orang-orang percaya mampu untuk menyatakan kesempurnaan Kristen yaitu suatu kehidupan yang mengasihi Allah dan sesama dengan sepenuh hati. Lagi pula menurut kaum Wesleyan, pengudusan yang menyeluruh meliputi penghancuran natur berdosa manusia yang mana semua dosa dalam

\footnotetext{
${ }^{11}$ Berkhof, 260-261.

${ }^{12}$ Berkhof, 261.

${ }^{13}$ Hoekema, 288.
} 
batin manusia disingkirkan. Pemahaman yang demikian oleh gerakan Wesleyan terhadap doktrin pengudusan sebenarnya berangkat dari titik berangkat Wesley mengenai aspek-aspek soteriologi. John Wesley mengikuti Jacob Armenian yang memercayai bahwa manusia memiliki kehendak bebas untuk memilih. Predestinasi dipahami oleh Arminius sebagai kemahatahuan Tuhan tentang siapa yang akan menerima keselamatan dan bertekun sampai akhirnya dan siapa yg akan menolaknya (sebagai konsekuensi dari kehendak bebas manusia). Arminius menekankan bahwa keselamatan diterima melalui iman percaya pada Tuhan Yesus; dan Kristus mati untuk semua orang. Karena itu, Wesley menekankan kekudusan dan pentingnya pengalaman kekudusan dalam kehidupan orang percaya. Wesley memercayai prevenient grace (kasih karunia yang terus berharap dan menunggu) sebagai sarana di mana orang-orang berdosa dapat menerima Kristus sebagai Juruselamat. Wesley sepaham dengan Arminius tentang ketekunan orang kudus dan pentingnya tanggung jawab pribadi mempertahankan keselamatan sampai akhir. ${ }^{14}$ Karena itu, pemahaman Wesley yang tidak membedakan antara pengudusan status dengan pengudusan progresif mengarah kepada pengudusan sebagai prasyarat keselamatan yang berbeda jauh dengan gerakan reformasi yang menekankan bahwa pengudusan adalah buah dari keselamatan (soteria). Pandangan pengudusan yang "perfeksionisme" ini dipegang oleh Wesleyan Methodist Church, Free Methodist Church, Salvation Army, Church of God, Christian and Missionary Alliance, Nazarene Church, dan Pilgrim Holiness Church ${ }^{15}$ serta sebagian besar kalangan Pentakosta dan New Pentacostal atau gerakan Karismatik Kontemporer.

Doktrin pengudusan dalam teologi modern ${ }^{16}$ mengalami distorsi. Dalam pengaruh rasionalisme dan moralisme dari filsuf pencerahan

\footnotetext{
${ }^{14}$ Lihat French L. Arrington, Jaminan Keselamatan Kekal Yang Tak Bersyarat (Jakarta: Light Publishing, 2015).

${ }^{15}$ Hoekema, 286-287.

${ }^{16}$ Gereja jaman modern (abad 17-19 M) mempunyai pertanyaan yang lain lagi tentang Allah. Objective Authority (apa yang gereja, teolog dan bahkan Alkitab katakan secara harafiah) tidak menarik lagi. Mereka merasakan betapa manusia sebenarnya ditentukan oleh cara berpikirnya sendiri (rasionalisme). Oleh sebab itu pertanyaan mereka yang terutama tidak lagi pada "apa yang Alkitab katakan, atau apa yang gereja katakan," melainkan, "bagaimana manusia bisa mengenal Allah dengan rasionya sendiri?". Semangat rasionalisme menguasai bagian pertama dari jaman modern, dan munculnya romanticisme telah mengubah pertanyaan manusia tentang Allah. Misalkan Friedrich Schleiermacher (1768-1834), bapak dari Teologi Modern, yang hidup dalam bagian kedua dari jaman modern ini, mengajukan suatu pertanyaan penting: "Bagaimana manusia dapat mengalami pengalaman iman yang sejati melalui perasaan (feeling)-nya?" Bagi dia, pengalaman dengan Allah tidak tergantung pada rasio manusia, tetapi pada pengalaman "batiniah" atau "perasaan ketergantungan padaNya/feeling of
} 
Immanuel Kant, pengudusan tidak lagi dianggap sebagai suatu karya supernatural dari Roh Kudus dalam transformasi kehidupan orang berdosa, dan pengudusan direndahkan menjadi sekadar peningkatan moral melalui kekuatan alami manusia. Menurut Friedrich Schleiermacher, pengudusan hanyalah sensasi perasaan (feeling) dan sering gagal secara moral dari kesadaran akan dunia. Sedangkan menurut Albrecht Ritscl, pengudusan adalah kesempurnaan moral dari kehidupan Kristen yang kepadanya manusia bersandar dengan cara memenuhi tugasnya sebagai anggota Kerajaan Allah. Menurut sebagian besar teolog modern, pengudusan hanya mencakup peningkatan moral saja. ${ }^{17}$

\section{Hakikat Doktrin Pengudusan Menurut Teologi Reformed}

Dalam segala sesuatu, gerakan reformasi maupun Teologi Reformed memberikan penekanan yang unik terhadap aspek "anugerah" (gratia). Teologi Reformasi Protestan mengikuti pendapat Augustinus (354-430) yang mengajarkan bahwa anugerah tidak tergantung pada syarat tertentu, melainkan harus dianggap sebagai pemberian belaka dari Allah. Para reformator maupun Augustinus menekankan anugerah sebagai kebaikan kehendak Allah yang ditunjukkan kepada orang berdosa, yang memberikannya dengan cara yang menyingkirkan semua jasa dari pihak orang berdosa. ${ }^{18}$ Bahkan mengikuti pendapat Augustinus pula, para reformator memahami anugerah mempengaruhi seseorang sebelum ia sendiri berkehendak, mendorong kehendaknya. Ia mengikuti akta berkehendak, kalau tidak demikian maka seseorang akan frustrasi. ${ }^{19}$ Ajaran anugerah ini bersifat "monergistis", yaitu keselamatan manusia hanya diperoleh melalui anugerah saja. Anugerah merupakan kekuatan yang mengubahkan yang mana mereka yang dipilih ditarik ke luar dari orang-orang yang terkutuk dan menerima keselamatan. ${ }^{20}$ Demikian pula

\footnotetext{
absolute dependency". Pada akhirnya Gereja abad XX adalah gereja yang mengalami kesulitan menformulasikan pertanyaan mereka tentang Allah. Karl Barth (1886-1968), mencoba membuktikan akan kepalsuan konsep Allah yang dibangun atas pengalaman rasio dan feeling manusia. Baginya Allah adalah Wholly Other yang sama sekali lain dari pada apa yang manusia rasakan, bayangkan, pikirkan dan alami. Barth ingin membawa gereja kembali pada konsep Allah yang trancendence. Tetapi munculnya pandanganpandangan teologi dari Albrecht Ritscl (1822-1899), Adolf von Harnack (1851-1930), Paul Tillich (1886-1965) dan pergolakan di Amerika Selatan dengan Teologi Pembebasannya (liberation theology) telah membawa gereja kembali pada kebutuhan akan konsep Allah yang dekat dengan manusia dan ciptaan. Lihat Susabda, 14-16.

${ }^{17}$ Berkhof, 261.

${ }^{18}$ Berkhof, 35-36.

${ }^{19}$ Bernhard Lohse, Pengantar Sejarah Dogma Kristen (Jakarta: BPK Gunung Mulia, 2011), 146.

${ }^{20}$ Dieter Becker, Pedoman Dogmatika (Jakarta: BPK Gunung Mulia, 2012), 140.
} 
dengan doktrin pengudusan (Sanctification) menurut teologi Reformed adalah anugerah juga bersamaan dengan aspek-aspek lain seperti kelahiran kembali, pembenaran, dan iman.

Istilah "kudus" secara harfiah didefinisikan dalam arti "dikhususkan, diistimewakan, dipisahkan, diabdikan kepada. Sesuatu yang "kudus" termasuk dalam kategori atau jenis lain. Allah adalah Kudus. Adapun semua orang yang dipanggil oleh Allah juga di jadikan-Nya kudus. Menurut Alkitab, Allah melalui Roh Kudus mengkhususkan mereka dan membuat mereka milik-Nya, di dalam Yesus Kristus. Itulah sebenarnya definisi dari gereja (1 Petrus 1:2). Proses ini disebut pengudusan (sanctification). Melalui proses ini, Roh Kudus berkarya untuk memulihkan dan memperbarui manusia sesuai dengan gambar dan rupa Allah, menjadi seseorang yang sepenuhnya mempercayakan dirinya kepada Tuhan Yesus Kristus dan anugerah Allah, seorang percaya kepada Tuhan Yesus Kristus dan taat kepada-Nya.

Dalam teologi Reformed, doktrin pengudusan (Sanctification) menempati domain yang penting dalam karya keselamatan yang dikerjakan oleh Allah Tritunggal. Pengudusan merupakan aspek penerapan penebusan yang dalam ordo salutis didahului oleh predestinasi, ${ }^{21}$ panggilan efektif, regenerasi, pembenaran dan adopsi. Menurut John Murray, pengudusan adalah karya Allah di dalam kita sebagai tindakan berdiamnya dan pengarahan Roh Kudus. ${ }^{22}$ Menurut Louis Berkhof, pengudusan adalah tindakan Roh Kudus yang penuh kasih karunia dan terus menerus, yang olehnya Ia membebaskan orang berdosa yang sudah dibenarkan dari kecemaran karena dosa memperbaharui keseluruhan naturnya dalam gambar dan rupa Allah dan memampukannya melakukan perbuatan baik. ${ }^{23}$ Sedangkan menurut Anthony A. Hoekema, pengudusan sebagai karya yang penuh anugerah dari Roh Kudus, yang melibatkan tanggungjawab kita untuk

\footnotetext{
${ }^{21}$ Predestinasi adalah aspek soteriologis yang sangat penting dalam gerakan Reformasi dan Teologi Reformed Gerakan reformasi mengikuti pengajaran Augustinus mengenai predestinasi sebagai anugerah Allah yang memilih sejumlah orang (tidak semuanya) untuk diselamatkan. Predestinasi merupakan kasih karunia yang bekerja dengan mendahului setiap kemanuan berbuat baik dari pihak manusia. Martin Luther mendukung pengajaran Augustinus tersebut, sedangkan Johanes Calvin melanjutkan bahkan mensistematiskan doktrin predestinasi. Menurut Calvin, predestinasi berarti bahwa jumlah dan jati diri dari orang-orang yang terpilih yakni mereka yang diselamatkan, sudah ditetapkan oleh Allah yang berdaulat itu sebelum dunia diciptakan oleh Allah. Predestinasi merupakan keputusan Allah yang kekal, yang dengannya Ia menetapkan untuk diri-Nya sendiri, apa yang menurut kehendak-Nya akan terjadi atas setiap orang. Lihat Aritonang, 100. 177.

22 John Murray, Penggenapan dan Penerapan Penebusan (Surabaya: Momentum, 2010),

${ }^{23}$ Berkhof, 265.
} 
berpartisipasi yang dengannya Roh Kudus melepaskan kita dari pencemaran dosa, memperbarui keseluruhan natur kita menurut gambar Allah, dan memampukan kita untuk menjalankan kehidupan yang diperkenan oleh Allah. ${ }^{24}$ Muriwali Yanto Matalu, seorang teolog Reformed asal Indonesia mendefinisikan pengudusan sebagai berkembang dan bertumbuhnya kehidupan rohani yang baru secara progresif, yakni hidup di dalam nilai dan norma Kerajaan Allah dan berkurang serta lenyapnya kehidupan yang lama, yakni kehidupan duniawi yang dipenuhi oleh rupa-rupa kecemaran dosa. ${ }^{25}$

Dalam perspektif teologi Reformed, setiap orang Kristen yang telah mengalami anugerah regenerasi disebut sebagai orang kudus, tetapi sekaligus mereka harus menguduskan diri. Pada satu sisi, pengudusan telah terjadi pada saat seseorang menjadi percaya kepada Tuhan Yesus Kristus (disebut pengudusan definitif atau pengudusan posisional), sehingga setiap orang Kristen disebut orang-orang kudus. Pengudusan definitif disebut juga sebagai pengudusan yang pasif, dalam pengertian orang percaya diberi pengudusan oleh Allah dengan tidak usah berubuat sesuatupun. ${ }^{26}$ Pada sisi yang lain pengudusan dipandang sebagai proses yang berlanjut seumur hidup (pengudusan progresif), yang artinya bahwa orang-orang kudus masih harus menguduskan diri (hal ini dipaparkan oleh rasul Paulus dalam 1 Korintus 1:2).

Berkaitan dengan aspek pengudusan dalam teologi reformed memandangnya bersifat paradoks. Pada satu sisi pengudusan berlangsung seumur hidup setiap orang percaya, yang berbeda dari pembenaran sebagai tindakan defintif Allah yang terjadi hanya sekali untuk selamanya. Namun pada sisi yang lain, pengudusan adalah suatu tindakan Allah yang definitif, yang terjadi pada suatu waktu tertentu ketimbang berlangsung dalam suatu jangka waktu tertentu. ${ }^{27}$

Adapun dalam teologi Reformed, maksud pengudusan definitif adalah pada saat setiap orang Kristen disebut sebagai "orang-orang yang dikuduskan" (Kisah Para Rasul 20:32; 26:18). Dalam 1 Korintus 1:2 di atas, rasul Paulus menyatakan mengenai orang-orang Kristen di Korintus sebagai "mereka yang dikuduskan (perfect tense) di dalam Kristus Yesus". Demikian pula dalam 1 Korintus 6:11, pengudusan dan pembenaran di sejajarkan: "Tetapi kamu telah memberi dirimu disucikan, kamu telah dikuduskan, kamu telah dibenarkan dalam nama Tuhan Yesus Kristus dan dalam Roh Allah kita". Adapun pengudusan yang dimaksudkan dalam teks tersebut telah terjadi pada saat seseorang menjadi percaya,

\footnotetext{
${ }^{24}$ Anthony A. Hoekema, 255-256.

${ }^{25}$ Muriwali Yanto Matalu, Dogmatika Kristen Dari Perspektif Reformed (Malang: Gerakan Kebangunan Kristen Reformed, 2015), 706.

${ }^{26}$ Soedarmo, Ikhtisar Dogmatika (Jakarta: BPK Gunung Mulia, 2013), 213.

${ }^{27}$ Hoekema, 270.
} 
sama seperti pembenaran. Pengudusan definitif memiliki kaitan dengan status setiap orang percaya sebagai anak-anak Allah, orang-orang benar, orang-orang kudus. Posisi atau status ini menjadi milik setiap orang percaya yang bersumber dari anugerah Allah sebagaimana pembenaran dan adopsi.

Adapun implikasi dari status setiap orang percaya sebagai "orang kudus" dalam pemahaman mengenai pengudusan definitif, tidak berarti bahwa mereka memiliki kesempurnaan tanpa dosa. Berangkat dari ajaran Alkitab, maka teologi Reformed menegaskan bahwa pengudusan definitif dalam diri setiap orang percaya harus melihat diri mereka sendiri dan sesamanya sebagai orang-orang percaya yang telah mati terhadap dosa dan sekarang menjadi pribadi-pribadi yang baru di dalam Yesus Kristus. Akan tetapi kebaruan (newness) yang dimiliki oleh orangorang percaya di dalam Kristus tersebut tidaklah berarti suatu kesempurnaan tanpa dosa. Selama seseorang masih hidup di dalam dunia ini, mereka masih harus bergumul melawan dosa dan seringkali bisa terjatuh ke dalam dosa. Oleh karena itu, maka setiap orang percaya harus melihat diri mereka sendiri dan sesamanya sebagai pribadi-pribadi yang sungguh-sungguh baru walaupun belum sepenuhnya baru (genuinely new, though not yet totally new). Dengan adanya pengudusan definitif tersebut menolong setiap orang percaya untuk memandang bahwa mereka yang berada di dalam Kristus telah mengadakan pemutusan yang penting serta tidak dapat dibatalkan terhadap dosa. ${ }^{28}$

Serangkaian dengan pengudusan definitif tersebut di atas, maka setiap orang Kristen sekaligus terlibat dalam proses pengudusan (pengudusan progresif). Paradoks pengudusan definitif dan progresif ini muncul dalam teks Roma 6. Pada satu sisi, setiap orang Kristen telah mati bagi dosa (ayat 2), yang mana "manusia lama kita telah turut disalibkan, supaya tubuh dosa kita hilang kuasanya" (ayat 6), dan kita "telah dimerdekakan dari dosa dan menjadi hamba kebenaran" (ayat 18). Itulah yang dimaksudkan dan ditegaskan mengenai pengudusan definitif. Namun pada sisi yang lain, setiap orang Kristen harus berusaha supaya "dosa jangan berkuasa lagi" di dalam tubuh kita yang fana (ayat 12), dan rasul Paulus menasihati setiap orang Kristen untuk jangan menyerahkan anggota-anggota tubuhnya kepada dosa untuk dipakai sebagai senjata kelaliman, melainkan untuk menyerahkan diri kita kepada Allah sebagai orang-orang, yang dahulu mati, namun yang sekarang hidup (ayat 13). Hal inilah yang disebut sebagai pengudusan progresif, yang mana pengudusan tersebut harus direalisasikan dalam kehidupan setiap orang percaya yang telah dikuduskan secara status. Dengan demikian setiap orang Kristen adalah orang kudus, walaupun

\footnotetext{
${ }^{28}$ Hoekema, 273.
} 
masih terdapat dosa dalam hidupnya, dan walaupun ia masih harus berusaha supaya ia hidup lebih kudus lagi. Pada saat seseorang menjadi percaya kepada Tuhan Yesus Kristus, statusnya telah berubah sehingga menjadi satu dengan Dia dalam kematian, penguburan dan kebangkitan$\mathrm{Nya}^{29}$

Sisi lain dari paradoks doktrin pengudusan dalam teologi Reformed, seperti yang telah dipaparkan di atas adalah realitas pengajaran Alkitab mengenai pengudusan merupakan proses seumur hidup karenanya bersifat progresif. Aspek progresif dari pengudusan begitu jelas melalui pernyataan-pernyataan Alkitab bahwa dosa masih hadir di dalam diri setiap orang percaya. Hal ini dinyatakan dalam Perjanjian Lama yakni dalam 1 Raja-raja 8:46; Mazmur 19:13; 143:2; Amsal 20:9 dan Yeremia 64:6. Sedangkan teks-teks Perjanjian Baru sangat jelas mengenai hal tersebut seperti dalam Roma 3:23 yang menyatakan bahwa "semua orang telah berbuat dosa". Di dalam tulisannya kepada orang-orang percaya, Yakobus menegaskan bahwa "kita semua bersalah dalam banyak hal" (Yakobus 3:2). Implikasinya adalah karena dosa terus ada di dalam orang-orang yang berada di dalam Kristus, maka pengudusan terhadap orang-orang percaya merupakan suatu proses yang berkelanjutan seumur hidup.

Dalam perspektif teologi Reformed, pengudusan progresif tetap merupakan pekerjaan Roh Kudus, namun melibatkan respons yang aktif dari setiap orang percaya untuk taat. Alkitab memerintahkan supaya setiap orang percaya hdup kudus (Roma 12:1; 13:12-13; 1 Tesalonika 4:7). Di dalam pengudusan progresif ini, Roh Kudus melakukan pekerjaan sepenuhnya untuk menguduskan orang-orang percaya, dan juga sepenuhnya dituntut suatu ketaatan dari orang-orang percaya yang telah menerima anugerah Allah. Melalui pengudusan progresif ini akan terealisasi perbuatan-perbuatan baik yang muncul dari iman yang benar sesuai dengan hukum Allah dan dilakukan untuk kemuliaan Allah. Adapun dalam pengudusan progresif tersebut tidak menjadikan orang percaya menjadi kudus secara instan, melainkan proses pengudusan ini berlangsung seumur hidup dan bersifat perlahan-lahan, sedikit demi sedikit namun progresif. Pengudusan membutuhkan proses yang tidak pendek dan membentuk setiap orang percaya menjadi orang Kristen yang baik membutuhkan waktu yang lama. Karena itu, rasul Paulus menegaskan bahwa seorang petobat baru tidak boleh diangkat menjadi penilik jemaat karena mereka bisa sombong (1 Timotius 3:6). Hal ini disebabkan karena seorang petobat baru belum matang di dalam iman dan juga belum teruji dalam kehidupan yang kudus. ${ }^{30}$

\footnotetext{
${ }^{29}$ Jan A. Boersema, (ed.), Berteologi Abad XXI (Jakarta: Literatur Perkantas, 2015), 689.

${ }^{30}$ Muriwali Yanto Matalu, 706-707.
} 
Dengan demikian dalam persepktif teologi Reformed, aspek pengudusan (sanctification) merupakan suatu paradoks. Pada satu sisi bersifat definitif atau status yang terjadi bersamaan dengan pembenaran (justification) serta terjadi di luar tindakan orang percaya karena merupakan anugerah Allah yang ajaib. Namun juga lambat laun harus menjadi pengalaman (experientia). Setiap orang percaya harus hidup kudus dalam memenuhi kehendak Allah. Kerapkali murid-murid Tuhan Yesus diwajibkan menjadi sempurna seperti Allah Bapa di Sorga juga sempurna. ${ }^{31}$ Inilah yang disebut sebagai pengudusan progresif. Hidup dalam pengudusan adalah hal penting sebagai realitas hidup baru dalam diri setiap orang percaya. Hidup baru tersebut bukanlah hidup yang mudah dan nyaman melainkan hidup yang penuh dengan peperangan, penuh pergumulan yakni pergumulan dengan dirinya sendiri, dengan manusianya yang lama, yang senantiasa ingin menyimpang dari ketaatan kepada Tuhan Allah. Hidup di dalam pengudusan adalah hidup yang harus disertai dengan pertobatan setiap hari. Dalam pergumulan terkait dengan proses pengudusan ini, setiap orang percaya akan sering mencucurkan air mata karena kegagalannya di bidang perjuangan rohani. Meskipun demikian, hidup baru di dalam pengudusan progresif ini bukanlah hidup yang tanpa harapan karena yang menguduskan setiap orang percaya adalah Tuhan Allah sendiri. ${ }^{32}$

\section{Pandangan Teologi Reformed Mengenai Hubungan Antara Pengudusan Dengan Aspek-Aspek Soteriologi Lainnya}

\section{Hubungan antara Pengudusan dengan Kelahiran Kembali}

Dalam perspektif teologi Reformed dengan tegas menyatakan bahwa kelahiran kembali bukanlah merupakan buah atau akibat dari iman, melainkan kelahiran kembali mendahului iman. Kelahiran kembali merupakan kondisi yang dibutuhkan oleh seseorang untuk beriman. Manusia juga tidak berpaling kepada kelahiran kembali atau bekerja sama sebagai rekan kerja dari Roh Kudus untuk menghasilkan kelahiran kembali. Manusia tidaklah memutuskan dan memilih untuk dilahirkan kembali. Allah saja yang memutuskan untuk melahirkan kembali manusia sebelum seseorang akan pernah memilih untuk menerima Dia. Adapun setelah manusia mengalami kelahiran kembali sebagai karya tunggal dari Allah dalam kedaulatan dan anugerah-Nya, maka manusia baru bisa memilih, bertindak, bekerja sama dan percaya kepada Tuhan Yesus Kristus. Allah tidak beriman untuk manusia. Manusia dibenarkan berdasarkan iman manusia itu sendiri. Apa yang dilakukan oleh Allah

\footnotetext{
${ }^{31}$ Soedarmo, 213.

${ }^{32}$ Harun Hadiwijono, Iman Kristen (Jakarta: BPK Gunung Mulia, 2012), 414.
} 
melalui kelahiran kembali adalah membangkitkan manusia dari keberadaannya yang mati secara rohani, Allah memberi kehidupan secara rohani, membebaskan dari kegelapan, keterikatan dan kematian secara rohani. Melalui kelahiran kembali, Allah memungkinkan manusia untuk percaya kepada-Nya. ${ }^{33}$

Hubungan antara kelahiran kembali terdapat perbedaan maupun persamaan. Kelahiran kembali diselesaikan dalam satu waktu saja, sebab seseorang tidak mungkin untuk kurang atau lebih dilahirkan kembali secara rohani sedangkan pengudusan adalah suatu proses yang menyebabkan terjadinya perubahan secara perlahan, sedikit demi sedikit. Kelahiran kembali adalah permulaan dari pengudusan. Karya pembaharuan yang dimulai dalam kelahiran kembali diteruskan dalam pengudusan.

\section{Hubungan antara Pengudusan dengan Pembenaran}

Yohanes Calvin menegaskan bahwa doktrin pembenaran sebagai landasan utama yang harus menjadi dasar agama Kristen, karena itu perlu mendapatkan perhatian dan kepedulian yang lebih besar. ${ }^{34}$ Karena kecuali seseorang terlebih dahulu memahami posisinya di hadapan Allah, dan hukuman apa yang dijatuhkan-Nya kepadanya, maka orang itu tidak memiliki landasan yang menjadi dasar bagi keselamatannya atau dasar untuk mempersembahkan kesalehan di hadirat Allah. Calvin bahkan menegaskan bahwa doktrin pembenaran adalah engsel utama yang padanya agama berputar ${ }^{35}$. Bagi para reformator, doktrin pembenaran merupakan tindakan anugerah dan yudisial (hukum) Allah yang dengannya Allah menyatakan bahwa orang-orang berdosa yang percaya sebagai orang benar berdasarkan kebenaran Tuhan Yesus Kristus yang diperhitungkan kepada mereka, mengampuni semua dosa mereka, mengangkat mereka sebagai anak-anakNya serta memberikan kehidupan kekal terhadap mereka. Karena itu bagi para reformator dan teologi Reformed, konsep pembenaran mempresaposisikan adanya pengakuan atas realitas dari murka Allah karena gelapnya dosa manusia. Pembenaran adalah suatu tindakan deklaratif atau yudisial dari Allah dan bukan merupakan suatu proses serta hal tersebut terjadi satu kali untuk selamanya pada saat seseorang menerima Tuhan Yesus Kristus melalui iman. Pembenaran yang diterima melalui iman oleh seseorang yang menerima Tuhan Yesus Kristus berarti pembenaran tersebut bukanlah pahala bagi perbuatan manusia. Karena itu, pembenaran

\footnotetext{
${ }^{33}$ R. C. Sproul. Kebenaran-Kebenaran Dasar Iman Kristen (Malang: Literatur SAAT, 2005), 228-229.

${ }^{34}$ Donald K. McKim, Encyclopedia of The Reformed Faith (Louisville, Kentucky: Westminer/John Knox Press, 1992), 337.

${ }^{35}$ Hoekema, 202.
} 
berakar dalam kesatuan dengan Yesus Kristus sehingga kebenaran Yesus Kristus diperhitungkan dan menjadi milik manusia yang beriman kepada-Nya. Pembenaran juga didasarkan kepada karya penggantian (substitusi) Yesus Kristus bagi kita. Hal ini melibatkan tindakan Kristus yang telah mengambil tempat kita dan menanggung bagi kita murka Allah terhadap dosa-dosa kita yang sebenarnya layak kita terima. Pada saat Yesus Kristus mati di atas kayu salib, Ia menanggung kutuk itu sebagai ganti kita manusia yang berdosa, sebagai pengganti kita, bahkan Ia telah menjadi kutuk demi kita, sehingga kita dapat diselamatkan dari kutuk tersebut. Bagi teologi Reformed, pembenaran mendahului dan merupakan dasar dari pengudusan dalam perjanjian anugerah (grace covenant). Pembenaran adalah dasar hukum dari pengudusan. Pembenaran merupakan pernyataan yang sama dengan pengudusan definitif, sekaligus pembenaran memicu "sikap dan perilaku benar" dalam pengudusan progresif.

Bagi para reformator, pembenaran segera diikuti oleh pengudusan, sebab Allah mengirimkan Roh Anak-Nya ke dalam hati umat-Nya segera sesudah mereka dibenarkan, dan Roh itu adalah Roh pengudusan. Anugerah pengudusan bukanlah sesuatu yang diterima manusia beriman melalui sakramen melainkan karya Roh Kudus yang oleh-Nya Ia melepaskan orang percaya terus-menerus dari kuasa dosa dan memampukannya untuk melakukan perbuatan baik. Dengan demikian bagi para reformator, pengudusan sebagai kelanjutan dari karya anugerah Allah yang telah membenarkan manusia beriman melalui Roh Kudus namun melibatkan tanggung jawab dan partisipasi manusia. Dengan pengudusan tersebut, Roh Kudus melepaskan seseorang dari pencemaran dosa, memperbaharui keseluruhan natur manusia menurut gambar Allah serta memampukan seseorang yang telah percaya kepada Tuhan Yesus Kristus untuk menjalankan kehidupan yang berkenan di hadapan Allah sebagai tujuan Allah yang penuh anugerah dalam menyelamatkan anak-anak-Nya di dalam Tuhan Yesus Kristus, Sang Juruselamat.

\section{Hubungan antara Pengudusan dengan Iman}

Menurut Yohanes Calvin iman yang sejati terdiri dari pengetahuan akan Allah, khususnya mengenai kasih setia Tuhan. Calvin menegaskan bahwa iman merupakan pengetahuan yang teguh dan pasti dari suatu janji yang bebas dalam Kristus serta diungkapkan dalam pikiran kita, dan dimeteraikan di dalam hati kita oleh Roh Kudus. ${ }^{36}$ Bagi Calvin iman tidaklah semata sebagai pengetahuan intelektual, namun seperti Martin Luther, Calvin mengajarkan bahwa kepercayaan adalah hakikat dari

${ }^{36}$ Berkhof, 188. 
iman. Iman adalah keyakinan yang teguh dan efektif. Selanjutnya Calvin menegaskan bahwa pengetahuan akan Kristus (sebagai objek iman) merupakan suatu pengajaran, namun bukan sekadar perkataan atau teor semata, melainkan sebagai suatu pengajaran dari kehidupan. Pengetahuan yang demikian bukan dipahami seperti disiplin-disiplin yang hanya terdiri dari pemahaman dan ingatan melulu, melainkan pengetahuan akan Kristus baru benar-benar akan dapat diterima apabila ia telah memiliki keseluruhan jiwa dan mendapatkan tempat bertakhta dan berdiam di dalam kasih yang paling dalam di hati manusia. Bagi para reformator, orang dibenarkan atau diselamatkan hanya melalui iman. Karena begitu pentingnya iman, maka mereka menjelaskan elemenelemen apa saja yang tercakup dalam iman yang menyelamatkan tersebut yang terdiri dari informasi, pengertian secara intelektual dan kepercayaan secara pribadi. Isi tercakup di dalam iman yang menyelamatkan karena manusia tidak dibenarkan atau diselamatkan hanya karena beriman pada apa saja. Alkitab menegaskan bahwa apa yang manusia percayai memiliki pengaruh yang sangat mendalam. Pengajaran atau doktrin yang benar yakni kebenaran-kebenaran dasar dari Injil merupakan suatu keharusan dalam iman yang menyelamatkan. Manusia harus percaya pada Injil yang menyaksikan akan pribadi dan karya Tuhan Yesus Kristus. Informasi yang benar mengenai pribadi dan karya Kristus juga mengharuskan adanya pikiran yang mengakui kebenaran dari hal itu. Seseorang harus mengakui bahwa apa yang Alkitab ajarkan mengenai kebenaran pribadi dan karya Yesus Kristus untuk menyelamatkan manusia melalui kematian dan kebangkitan-Nya serta realitas bahwa hanya di dalam Yesus Kristus satu-satunya jalan keselamatan bagi manusia berdosa adalah unsur penting bagi iman yang menyelamatkan. Pemahaman dan pengakuan akan kebenaran-kebenaran Injil adalah unsur penting dalam iman, namun masih ada satu unsur lagi yakni percaya untuk memperoleh iman yang menyelamatkan yang melibatkan penyerahan diri seseorang dan kebergantungan dirinya pada Tuhan Yesus Kristus sebagai Tuhan dan Juruselamat. Kepercayaan secara pribadi mutlak perlu bagi seseorang untuk memperoleh keselamatan dan merupakan hal yang ada setelah pengertian secara intelektual. Hal inilah yang diungkapkan oleh Martin Luther bahwa iman adalah kepercayaan yang vital dan pribadi kepada Kristus sebagai Juruselamat dan Tuhan. ${ }^{37}$

Menurut teologi Reformed, iman adalah pengantara atau alat yang menyebabkan pengudusan. Iman menyatukan seseorang dengan Kristus serta memelihara setiap orang percaya untuk bersatu dengan Yesus Kristus sebagai kepala dari manusia baru. Hal ini merupakan sumber

${ }^{37}$ Sproul, 249. 
dari hidup baru dalam diri setiap orang percaya yang mana Roh Kudus melakukan tindakan pengudusan progresif bagi mereka. Pengudusan didasari atas adanya pembenaran, karena itulah dalam pengudusan membutuhkan suatu tindakan iman yang konstan supaya akan meningkatkan keberadaan orang percaya untuk hidup dalam kekudusan dan memelihara setiap orang percaya dalam pergumulan untuk menghasilkan kebajikan. Karena itu, iman menjadi pengantara dalam proses pengudusan setiap orang percaya yang berbanding lurus dengan ketaatannya terhadap Kristus. ${ }^{38}$

\section{Aspek-Aspek Pengudusan Menurut Teologi Reformed}

Adapun yang akan dibahas berkaitan dengan aspek-aspek pengudusan pada bagian ini adalah mengenai pengudusan definitif maupun pengudusan progresif dalam perspektif teologi Reformed. Akan tetapi yang akan banyak ditinjau adalah mengenai pengudusan progresif yang merupakan pengalaman hidup dalam perjalanan dengan Allah seumur hidup. Penekanannya tetap kepada karya Allah Roh Kudus dalam menguduskan setiap orang percaya yang telah dibenarkan di dalam darah Tuhan Yesus Kristus, namun setiap orang percaya yang telah dibenarkan dan dinyatakan sebagai "orang kudus" secara difinitif harus bekerja keras untuk hidup makin kudus, dan untuk menjauhkan diri dari dosa serta senantiasa bertahan dalam segala macam pencobaan yang terdapat dalam kehidupan setiap orang percaya. Hal ini merupakan pergumulan yang berat yang akan berlangsung seumur hidup kita.

Indikatif/Pernyataan: Pengudusan Adalah Status Setiap Orang Yang Percaya

Seperti yang telah diuraikan di atas bahwa dalam perspektif teologi Reformed, pengudusan definitif merupakan fakta pengudusan seseorang pada saat kelahiran kembali dan penerimaan Kristus. Di dalam Kristus, orang yang percaya tersebut diterima oleh Allah sebagai orang kudus. Posisi atau status kudus setiap orang percaya dan status kudus umat Tuhan tidak dapat dipersoalkan atau diragukan. ${ }^{39}$

Tuhan Yesus Kristus adalah kudus (Lukas 1:35), maka semua orang percaya adalah kudus di dalam Dia (1 Korintus 1:30). Hal ini ditegaskan oleh Petrus pada saat ia menulis: "kamulah bangsa yang terpilih, imamat yang rajani, bangsa yang kudus, umat kepunyaan Allah sendiri" (1 Petrus 2:9).

\footnotetext{
${ }^{38}$ Berkhof, 276-277.

${ }^{39}$ Boersema, (ed.), 621.
} 
Imperatif/Perintah: Pengudusan Adalah Perintah Bagi Setiap Orang Percaya

Pengudusan definitif yang bersifat indikatif di atas berbarengan dengan pengudusan progresif yang bersifat imperatif yaitu perintah untuk bekerja, taat dan hidup kudus. Seorang percaya dikuduskan (=dipisahkan/dikhususkan) untuk hidup saleh, hidup sebagai surat Kristus yang dibaca oleh sesamanya. Bahkan Allah memilih seseorang dalam tindakan predestinasinya dengan tujuan supaya seseorang menjadi kudus (Efesus 1:4). Kredo Nicea menyatakan bahwa gereja adalah gereja yang satu, kudus, katolik/am/universal dan apostolik/rasuli. Pernyataan "kudus" tidak berarti bahwa gereja serta setiap anggotanya secara individu harus hidup mengucilkan diri dari dunia. Akan tetapi mereka berada di tengah dunia ini sebagai "orang asing" (karena telah dikuduskan), namun dengan keberadaan dan tugas untuk memberitakan Injil, untuk mengasihi, dan untuk melayani. Dengan demikian status kudus memicu hidup kudus. Kekudusan di dalam Kristus mengimplikasikan perintah untuk berlaku kudus dalam segala bidang, baik etika sosial, politik dan bisnis. ${ }^{40}$ Tidak ada satu bidang kehidupan manusia yang dikecualikan dalam perintah kepada setiap orang percaya untuk hidup dalam kekudusan.

Realitas Paradoks: Pengudusan Sebagai Status Dan Proses Sebagai Realitas Kehidupan Orang Percaya Yang Tidak Mudah

Seperti yang telah diungkapkan di atas bahwa aspek pengudusan (sanctification) dalam perspektif Teologi Reformed bersifat paradoks. Paradoks antara "posisi" dan "pengalaman", paradoks antara "telah" dan "belum". Paradoks ini juga merupakan suatu realitas. Dalam proses pengudusan, maka kebergantungan setiap orang percaya kepada Tuhan Yesus adalah merupakan hal yang mendasar. Setiap hari setiap orang percaya mengalami tantangan, masalah dan persoalan yang berat dengan sistem dunia yang memberontak kepada Allah. Karena itu, setiap orang percaya dalam pergumulan untuk pengudusan dirinya secara keseluruhan harus bergantung kepada Tuhan Yesus Kristus, supaya dapat melawan godaan, menghasilkan buah Roh/karakter Kristus serta melayani sesama. ${ }^{41}$

Sinergi: Pengudusan Adalah Anugerah Allah Dan Keterlibatan Setiap Orang Percaya

Dalam perspektif teologi Reformed, keselamatan bersifat monergi yaitu karya Allah Tritunggal yang penuh anugerah bagi manusia. Allah Bapa yang memilih dalam kekekalan/predestinasi (Efesus 1:4), Tuhan Yesus Kristus yang menebus oleh darah-Nya (Efesus 1:7) dan Roh Kudus

\footnotetext{
${ }^{40}$ Boersema, (ed.), 622.

${ }^{41}$ McKim, 337-338.
} 
yang memeteraikan (Efesus 1:13). Dengan tinggalnya Roh Kudus dalam kehidupan setiap orang percaya, maka setiap orang percaya telah memiliki kodrat ilahi (2 Petrus 1:4). Dalam pengudusan, setiap orang percaya mengalami suatu keberadaan yang baru. Statusnya menjadi baru melalui kelahiran kembali dan posisinya yang baru melalui pembenaran. Melalui pembenaran, maka Roh Kudus menuntun setiap orang percaya dalam kehidupan yang saleh dan taat sebagai ungkapan syukur atas anugerah Allah yang menyelamatkan. Namun diri setiap orang percayalah yang harus menjalankan ketaatan dan kehidupan yang saleh seumur hidupnya untuk menjadi anak-anak terang dan senjata-senjata kebenaran.

Teologi Reformed sangat ketat dengan pernyataan keterlibatan manusia dalam pengudusan. Apabila disebutkan bahwa manusia mengambil bagian (sinergi) dalam proses pengudusan, hal ini tidak berarti bahwa manusia adalah pelaku bebas dari pekerjaan pengudusan tersebut, sehingga dikatakan bahwa pengudusan adalah sebagian hasil pekerjaan Tuhan dan sebagian lagi adalah hasil pekerjaan manusia. Namun sesungguhnya, hanya Tuhan yang memungkinkan pekerjaan pengudusan tersebut melalui manusia sebagai alat. Tuhanlah yang menggerakkan manusia untuk berdoa dan bekerja bersama-sama dengan Roh Kudus dalam pengudusan. ${ }^{42}$ Setiap orang percaya memang harus bekerja bersama dengan Roh Kudus dalam proses pengudusan tersebut sebagaimana yang dinyatakan oleh Alkitab bahwa setiap orang percaya harus melawan dan mengalahkan pencobaan dan kejahatan. Hal ini menegaskan bahwa setiap orang percaya harus bertindak aktif dalam mengalahkan segala godaan dalam kehidupan (Roma 12:9, 16-17; 1 Korintus 6:9-10; Galatia 5:16-23). Setiap orang percaya juga dipanggil dan diperintahkan untuk terus-menerus hidup dalam kekudusan. Mereka harus giat memakai semua sarana yang Tuhan anugerahkan kepadanya untuk meningkatkan kehidupan yang rohani dan karakter yang sepadan dengan karakter Kristus.

\section{Mortificatio: Pengudusan Adalah Kematian Manusia Lama}

Alkitab menggambarkan hal ini sebagai tindakan Allah yang mana kecemaran dan kerusakan natur manusia (depravity of man) yang merupakan akibat dari dosa setahap demi setahap disingkirkan. Proses pengudusan ini dinyatakan oleh Alkitab sebagai penyaliban manusia lama yang dikaitkan dengan kematian Tuhan Yesus Kristus di salib. Manusia lama adalah natur manusia yang masih dikuasai dosa sebelum seseorang memercayai Tuhan Yesus Kristus.

\footnotetext{
${ }^{42}$ Berkhof, 268.
} 
Dalam keberadaan sebagai "orang kudus" dengan statusnya yang baru di dalam Kristus, maka bagi setiap orang percaya keberadaan manusia lama telah turut disalibkan atau telah mati (Roma 6:6). Karena itu, setiap orang percaya harus memandang bahwa mereka telah mati bagi dosa, tetapi hidup bagi Allah dalam Kristus Yesus (Roma 6:11). Karena itu dosa jangan lagi berkuasa atas kehidupan setiap orang percaya. Setiap orang percaya harus membuang segala hawa nafsu dan keinginannya sebagai sifat-sifat dari manusia lama. Sifat-sifat manusia lama yang disebut oleh Paulus sebagai perbuatan daging, yakni Perbuatan daging telah nyata, yaitu: percabulan, kecemaran, hawa nafsu, penyembahan berhala, sihir, perseteruan, perselisihan, iri hati, amarah, kepentingan diri sendiri, percideraan, roh pemecah, kedengkian, kemabukan, pesta pora dan sebagainya. (Galatia 5:19-21). Semua hal itu tidak boleh lagi menjadi perilaku setiap orang percaya yang telah menyalibkan daging dengan segala hawa nafsu dan keinginannya. Karena Roh Kudus saat ini telah mendiami dan menguasai setiap orang percaya. $^{43}$

\section{Vivificatio: Pengudusan Adalah Kebangkitan Manusia Baru}

Anugerah yang besar bagi kehidupan setiap orang percaya adalah setiap orang percaya telah mengenakan manusia baru (Efesus 4:24; Kolose 3:10). Status setiap orang percaya yang telah dilahirkan kembali oleh Roh Kudus memicu orang tersebut untuk memiliki keinginan untuk hidup sepadan dengan status tersebut. Setiap orang percaya telah mati bagi dosa, maka ia hidup bagi Allah. Setiap orang percaya sudah disalibkan dan dibangkitkan bersama dengan Kristus, maka ia bebas dari dosa. Roh Kudus terus menerus bersaksi dalam dirinya. Oleh sebab itu, maka setiap orang percaya tidak hidup lagi menurut daging, melainkan oleh Roh Kudus ia mematikan perbuatan-perbuatan tubuhnya (Roma 8:13). Inilah salah satu keagungan dari aspek pekerjaan Roh Kudus dalam diri setiap orang percaya pada masa kini yakni pengudusan (Santification). ${ }^{44}$ Seseorang yang menjadi milik Yesus Kristus, maka ia telah menyalibkan daging dengan segala hawa nafsu dan keinginannya. Apabila ia hidup oleh Roh, maka baiknya hidupnya juga dipimpin oleh Roh (Galatia 6:24-25). Dengan demikian maka kehidupannya akan menghasilkan buah Roh, yakni kasih, sukacita, damai sejahtera, kesabaran, kemurahan, kebaikan, kesetiaan, kelemahlembutan, penguasaan diri (Galatia 5:22-23). Karena itu, pengudusan berarti juga terwujudnya kehidupan yang baru (dalam pengalaman hidup sehari-

\footnotetext{
${ }^{43}$ Berkhof, 267.

${ }^{44}$ Boersema, (ed.), 624.
} 
hari) dalam diri setiap orang percaya yang telah mengenakan manusia baru di dalam Kristus.

Pengudusan adalah tindakan Allah yang mana sikap jiwa yang kudus diperkuat, tindakan-tindakan-tindakan yang kudus makin meningkat, jalan hidup yang baru diperlihatkan oleh setiap orang percaya. Struktur lama dari manusia yang cenderung berdosa dibuang dan struktur baru yang dari Allah yang telah mengaruniakan "kodrat atau benih ilahi" dalam diri setiap orang percaya menempati kehidupan dalam diri orang tersebut. Kedua hal ini dalam pengudusan tidak terjadi dalam urutan-urutan melainkan terjadi bersama-sama. Pada waktu seseorang menerima Tuhan Yesus Kristus, maka manusia lamanya telah mati tersalib dan ia mengenakan manusia baru. Adapun efek dosa yang merupakan pengaruh dari manusia lama perlahan-lahan musnah dan buah Roh sebagai hakikat dari manusia baru itu muncul. Pengudusan sering disebut dalam Alkitab "dibangkitkan bersama-sama dengan Kristus" (Roma 6:4-5; Kolose 2:12; 3:1-2). Hidup yang baru yang dihidupi oleh manusia baru adalah sebuah hidup bagi Tuhan (Roma 6:11; Galatia 2:19). ${ }^{45}$

\section{Imitatio Christi: Pengudusan Adalah Mengikut Yesus Kristus}

Teladan ketaatan yang paripurna adalah Yesus Kristus. Sebagai manusia, Yesus Kristus juga mengalami pergumulan yang sama dengan manusia lainnya dalam melawan godaan iblis dan dosa serta mewujudkan ketaatan sepenuhnya kepada Allah Bapa. Pergumulan dengan segala dosa adalah pergumulan yang tidak ringan. Pada satu sisi, pergumulan setiap orang percaya dibandingkan dengan suatu perlombaan atau pertandingan yang seru. Setiap orang percaya harus berlomba dengan tekun untuk mengikuti Tuhan Yesus Kristus. Supaya memperoleh kemenangan dalam perlombaan tersebut, maka ia harus melepaskan semua beban dan dosa yang merintanginya, dan berlomba dengan tekun (Ibrani 12:2). Karena itu hendaknya mata setiap orang percaya harus tertuju kepada Yesus yang memimpinnya dan membawa imannya kepada kesempurnaan. Tuhan Yesus Kristus berfirman: "Akulah terang dunia; siapa saja yang mengikut Aku, ia tidak akan berjalan dalam kegelapan, melainkan ia akan mempunyai terang kehidupan (Yohanes 8:12). Setiap orang percaya harus menjadi penurut Allah (Efesus 5:1). Rupa Kristus harus menjadi nyata di dalam kehidupannya (Galatia 4:19). Bagi setiap orang percaya, Alkitab menyatakan bahwa "kita di dalam Kristus dan Kristus di dalam kita" (2 Korintus 13:4-5; Roma 8:1, 10). Maka setiap orang percaya mengalami hubungan yang misterius dengan Yesus Kristus. Dalam hubungan rohani

\footnotetext{
${ }^{45}$ Berkhof, 267.
} 
tersebut terdapat suatu interaksi timbal balik, suatu simbiosis atau kehidupan bersama. Hal inilah yang memampukan setiap orang percaya untuk meneladani/mengikut Yesus Kristus dalam hubungan yang ajaib dengan Dia.

Imitatio Christi berarti bahwa setiap orang percaya tetaplah seorang manusia biasa yang masih tergoda oleh dosa. Dosa memang merupakan suatu realitas masa lalu, namun dosa masih terus menggoda. Dalam keadaan seperti itu, ia bukan lagi a happy sinner yang bahagia, bangga dan enjoy dengan dosa melainkan a disturbed sinner yang senatiasa sedih, gelisah dan marah pada dirinya sendiri karena masih kerap kali tergoda dengan dosa. $^{46}$

\section{Obidientia: Pengudusan Adalah Ketaatan Kepada Nilai-Nilai Kerajaan Allah}

Pengudusan adalah ketaatan dan ketaatan adalah sikap dan perilaku yang sangat mendasar dalam kehidupan orang percaya kepada Tuhan Yesus Kristus. Dalam perspektif teologi Reformed karya anugerah Allah yang menyelamatkan yang meliputi pekerjaan Roh Kudus yang melakukan panggilan efektif, kelahiran kembali dan iman pada seseorang tidak mungkin akan membuat seseorang murtad dan kembali kepada ketidaktaatan manusia lama. Keberadaan setiap orang percaya yang telah dikuduskan secara status melalui pengudusan definitif, menuntun orang percaya tersebut kepada suatu sikap dan perilaku ketaatan terhadap Tuhan Yesus Kristus.

Hal inilah yang menjadi ciri khas seorang Kristen yang reformed, yakni sikap dan kesediaan yang selalu taat kepada firman Tuhan. ${ }^{47}$ Berkaitan dengan ketaatan (obedientia) tidaklah berarti bahwa gereja memiliki suatu daftar yang lengkap dengan hukum-hukum dan petunjuk-petunjuk dari surga yang harus ditaati di bumi ini. Alkitab yang adalah firman Allah tidaklah berisi daftar yang demikian. Ketaatan juga bukan merupakan suatu keberadaan moral yang statis dan tetap sama bagi setiap generasi dan segala tempat. Dalam proses kehidupannya, setiap orang percaya harus memutuskan hal yang harus dilaksanakan sesuai dengan kehendak Allah. Ketaatan adalah sikap yang senantiasa sedia untuk mendengar dan melakukan firman Tuhan seperti yang diungkapkan Paulus dalam 2 Timotius 3:16 bahwa firman Tuhan bermanfaat untuk mengajar, untuk menyatakan kesalahan, untuk memperbaiki kelakuan dan untuk mendidik orang dalam kebenaran.

Setiap orang percaya adalah warga-warga Kerajaan Allah. Kerajaan Allah adalah pemerintahan Allah atas segenap aspek kehidupan ini.

\footnotetext{
${ }^{46}$ Ebenhaizer Nuban Timo, Allah Menahan Diri Tetapi Pantang Berdiam Diri: Satu Upaya Berdogmatika Kontenstual di Indonesia (Jakarta: BPK Gunung Mulia, 2015), 316-317.

${ }^{47}$ Boersema, (ed.), 625.
} 
Kerajaan Allah adalah bertakhtanya Allah atas segenap ciptaan-Nya yang mana Allah senantiasa aktif dan dinamis berperan dalam sejarah manusia melalui Yesus Kristus. Maka menjadi hamba Kerajaan Allah berarti taat kepada Allah dalam segala bidang kehidupan. Karena itu setiap orang percaya dalam seluruh aspek kehidupan harus tunduk berada di bawah ketuhanan Kristus. ${ }^{48}$ Inilah dimensi pengudusan yang dituntut Allah bagi anak-anak-Nya yang telah dikuduskan oleh-Nya.

\section{Perseverentia: Pengudusan Adalah Ketekunan Setiap Orang Percaya}

Salah satu elemen penting dalam teologi Reformed adalah ketekunan orang percaya yang telah dikuduskan (perseverance of the saints) sebagaimana yang tercantum dalam ajaran Dordrecht. Sebenarnya esensi dari ketekunan orang percaya adalah kegigihan Allah atau ketekunan Allah untuk menyelamatkan manusia secara tuntas sebagai ekspresi dari anugerah dan kedaulatan-Nya yang kekal. Dialah yang bertekun dengan tidak melepaskan seseorang yang telah dipilih dan dilahirkan kembali oleh Roh Kudus. Karya Roh Kudus yang melahirkan kembali dan menanamkan iman serta menguduskan seseorang di dalam Yesus Kristus berlaku untuk selama-lamanya. Sekalipun demikian ketekunan atau kesetiaan Allah tidak berarti setiap orang percaya memiliki kebebasan untuk berdosa. Setiap orang percaya yang berbuat dosa akan mendukakan Roh Kudus dan akan mengalami kehilangan damai sejahtera sebagai didikan dan disiplin dari Allah. Namun yang menjadi sandaran bagi setiap orang percaya yang senantiasa memiliki kelemahan dalam pergumulan melawan dosa adalah kesetiaan Allah. Allah senantiasa akan menyinari mereka, sehingga memimpin mereka kepada pertobatan setiap hari. Hal ini terjadi sebab Roh Kudus senantiasa menyertai setiap orang yang percaya dalam situasi apapun termasuk Roh Kudus tetap memelihara setiap orang percaya yang berdosa. Benih atau kodrat ilahi tetap berada di dalam diri setiap orang percaya. Karena itu, setiap orang percaya diperbarui-Nya melalui Roh Kudus dan firman Allah. Pemeliharaan Yesus Kristus tidak mungkin dibatalkan, demikian juga pemeteraian Roh Kudus tidak dapat digagalkan atau dimusnahkan. ${ }^{49}$ Doktrin ketekunan orang-orang kudus (perseverance of the saints), yang sebenarnya merupakan kegigihan atau ketekunan Allah untuk menyelamatkan dengan tuntas orang-orang yang dikasihiNya di dalam Kristus sungguh merupakan hal yang ajaib. Hal ini merupakan akar kerendahan hati, damai sejahtera seorang anak, kesalehan yang sejati, kesabaran dalam segala pergumulan dan perjuangan hidup, doadoa yang bersungguh hati, ketabahan dalam memikul salib/penderitaan

\footnotetext{
${ }^{48}$ Hoekema, 307.

${ }^{49}$ Boersema, (ed.), 625.
} 
karena iman kepada Kristus serta dalam mengakui dan mengikuti kebenaran serta sukacita yang teguh di dalam Allah. Melalui Roh Kudus, Allah yang setia senantiasa tetap memelihara, meneruskan dan menyelesaikan karya penyelamatan-Nya bagi mereka yang Ia kasihi di dalam Kristus. Banyak hal dan cara yang digunakan oleh Allah untuk mengerjakan ketekunan dalam diri setiap orang percaya yakni melalui membaca, mendengarkan dan merenungkan firman Tuhan, dengan nasihat-nasihat, ancaman-ancaman, teguran-teguran, janji-janji dan juga dengan sakramen. ${ }^{50}$ Oleh karena tidak ada rencana yang dapat dilaksanakan oleh oknum dan kuasa apapun untuk melawan Allah, tidak ada satu oknum dan kuasa manapun yang bisa menggagalkan karya penyelamatan Allah pada setiap orang percaya, maka hanya Dia sajalah yakni Bapa dan Anak dan Roh Kudus yang layak menerima segala hormat dan kemuliaan yang kekal.

\section{Glorifikasi: Pengudusan Final}

Dalam perspektif teologi Reformed, pemuliaan (glorification) adalah pengudusan yang sempurna/konsumasi atau pengudusan final (final sanctification). Pemuliaan berarti bahwa orang-orang percaya dibebaskan dari kehadiran (keberadaan) dosa (saved from the presence of sin). Perjanjian Baru sangat menekankan kebenaran bahwa kehidupan Kristen adalah kehidupan yang bertumbuh, yaitu menuju kepada kepenuhan yang mulia yang mana keselamatannya akan disempurnakan atau digenapi secara penuh. Paulus dalam Efesus 1:14 menyatakan: "Dan Roh Kudus itu adalah jaminan bagian kita sampai kita memperoleh seluruhnya, yaitu penebusan yang menjadikan kita milik Allah, untuk memuji kemuliaannya." Jaminan ini didasarkan pada kebenaran bahwa "...semua yang dipilih-Nya dari semula, mereka juga ditentukan-Nya...dan mereka yang ditentukan-Nya dari semula, mereka itu juga dipanggil-Nya. Dan mereka yang dipanggil-Nya, mereka itu juga dibenarkan-Nya. Dan mereka yang dibenarkan-Nya, mereka itu juga dimuliakan-Nya"(Roma 8:29-30). Dengan demikian pengudusan definitif memicu pengudusan progresif dalam proses kehidupan setiap orang percaya yang pada akhirnya menuju kepada pengudusan final yang mana setiap orang percaya akan dimuliakan bersama-sama dengan Dia yang telah menebus mereka.

\section{Karakteristik Pengudusan Menurut Teologi Reformed}

Telah menjadi jelas bahwa dalam teologi Reformed, pengudusan adalah karya yang mana Allah yang mengerjakannya dan bukan manusia. Mulai dari pengudusan defintif yang menyatakan bahwa Allah

\footnotetext{
${ }^{50}$ Boersema, (ed.), 628.
} 
menguduskan (memisahkan/mengkhususkan) di dalam Kristus setiap orang yang telah menerima anugerah keselamatan di dalam Yesus Kristus dan menyatakan orang-orang yang demikian sebagai "orang kudus". Pengudusan definitif kemudian memicu pengudusan progresif dalam diri setiap orang percaya, yang mana Allah melalui Roh Kudus yang mengerjakan hal itu dalam diri orang percaya, menggerakkan dan memberi kekuatan pada setiap orang percaya untuk hidup dalam kekudusan dalam pengalaman sehari-hari. Akan tetapi memang pengudusan berbeda dengan kelahiran kembali (regenerasi), karena merupakan pekerjaan Roh Kudus atas manusia yang secara rohani telah mati karena realitas dosa. Roh Kudus menciptakan kembali hati manusia, membangkitkannya dari kematian secara rohani dan memberikan kehidupan secara rohani. Manusia yang mengalami kelahiran kembali adalah ciptaan yang baru. Pada awalnya manusia tersebut tidak memiliki posisi, kecenderungan maupun kerinduan untuk hal-hal yang berasal dari Allah, namun setelah kelahiran kembali tersebut sekarang manusia itu berpaling dan memiliki kecenderungan dan kerinduan kepada Allah. Di dalam kelahiran kembali tersebut hidup baru itu dimanifestasikan. Kelahiran kembali adalah penanaman kehidupan yang baru di dalam jiwa, terlepas dari manifestasi pertama dari kehidupan ini. ${ }^{51}$ Dengan demikian kelahiran kembali bukanlah hasil kerja sama antara Allah dengan manusia, melainkan karya Allah semata yang kemudian menghasilkan pertobatan dan membawa kepada kehidupan yang taat dan kudus. Sedangkan dalam pengudusan, manusia ikut serta di dalamnya dan wajib untuk selalu berusaha meningkatkan pengudusan tersebut dengan menggunakan semua sarana yang dianugerahkan Tuhan kepadanya (2 Korintus 7:1; Kolose 3:5-14; 1 Petrus 1:22).

Dalam teologi Reformed, pengudusan tidak terlepas dari misteri Allah yang bekerja dalam batin manusia sehingga terjadi sebagian dalam hidup bawah sadar manusia melalui tindakan langsung dari Roh Kudus dan sebagian lagi pengudusan terjadi dalam kehidupan sadar manusia. Dalam hal ini setiap orang percaya harus menggunakan sarana-sarana yang dianugerahkan oleh Allah kepadanya yakni tindakan iman yang terus-menerus, mempelajari Alkitab sebagai firman Tuhan, berdoa dan bersekutu dengan setiap orang percaya yang lain serta menerapkan ketaatan dalam hidupnya.

Sebagai suatu proses, maka pengudusan sesuatu yang terjadi perlahan-lahan dan berkepanjangan yang tidak pernah mencapai kesempurnaan dalam hidup masa sekarang ini. Akan tetapi pada kasus tertentu, pengudusan itu disempurnakan dalam suatu waktu yang

${ }^{51}$ Berkhof, 122. 
singkat dan sejenak, seperti kasus penyamun yang bertobat pada samping Yesus di Salib. Hal ini terjadi pada seseorang yang mengalami kelahiran kembali dan pertobatan yang segera diikuti oleh kematian jasmani. Dengan demikian pengudusan manusia akan menjadi sempurna pada saat Tuhan Yesus Kristus datang kembali dan menyempurnakan setiap orang percaya dalam pemuliaan (glorifikasi).

\section{Pandangan Teologi Reformed Mengenai Sarana-Sarana Pengudusan}

Teologi Reformed yang berasal dari tradisi pengajaran Agustinus dan reformator Martin Luther dan Johanes Calvin memberikan penekanan yang kuat terhadap keselamatan yang merupakan anugerah Allah saja (Sola Gratia/Grace Alone). Pengudusan yang mengarah kepada pertumbuhan rohani (spiritual formation) orang percaya juga bukan merupakan hasil upaya dan pekerjaan manusia melainkan sebagai karya anugerah Allah. Sebagaimana aspek keselamatan lainnya, maka dalam pengudusan manusia tidak memiliki jasa apapun yang ia kontribusikan. Pengudusan terjadi dalam kehidupan bawah sadar manusia melalui tindakan Roh Kudus terhadapnya. Untuk pekerjaan pengudusan tersebut, maka Roh Kudus memakai beberapa sarana penerapannya dalam diri setiap orang percaya, yaitu:

Firman Allah. Dalam perspektif teologi Reformed, sarana yang paling mendasar yang digunakan oleh Roh Kudus dalam karya pengudusan adalah firman Allah. Kebenaran manusia tidak memiliki kemampuan dan kekuatan yang memadai untuk menguduskan setiap orang percaya, namun firman Tuhan adalah sarana utama yang dipakai oleh Roh Kudus dalam pengudusan setiap orang percaya. Alkitab memuat segala hal dan objektif bagi tindakan yang kudus yang menjadi kegendak Allah melalui dorongan dan pengarahan, perintah dan larangan serta ajakan dan contoh-contoh serta pengalaman praktis.

Sakramen. Dalam perspektif Reformed, sakramen bukanlah jalan atau cara pengudusan. Sakramen berada di bawah firman Tuhan akan tetapi merupakan juga wujud dari firman Tuhan atau "Firman yang tampak." S2 Sakramen Baptisan Air dan Perjamuan Kudus melambangkan dan memeteraikan kebenaran dengan mewujudkan secara kelihatan, verbal dan dalam tindakan firman Tuhan sehingga firman menjadi pernyataan yang hidup dan kebenaran. Melalui sakramen, Roh Kudus mengerjakan perbuatan yang suci dari orang-orang percaya dengan mereferensi kepada firman Tuhan.

Tuntutan pemeliharaan Allah. Providensia adalah sarana yang sangat berkuasa bagi pengudusan setiap orang percaya. Roh Kudus yang

${ }^{52}$ Berkhof, 122. 
bekerja melalui firman Tuhan juga mengerjakan pemeliharaan (providensia) atas perasaan alamiah manusia dan dengan terus menerus menanamkan kebenaran dan membimbing setiap orang percaya untuk hidup sepadan dengan statusnya sebagai "orang kudus" yakni hidup dalam kebenaran firman Tuhan.

\section{Relevansi Doktrin Pengudusan Pada Masa Kini}

Dengan penjelasan di atas secara panjang dan lebar pandangan Teologi Reformed mengenai doktrin pengudusan (sanctification) maka beberapa relevansinya pada masa kini dapat diuraikan sebagai berikut:

Pertama, pengudusan adalah karya anugerah Allah sebagaimana aspek-aspek lain dalam doktrin keselamatan (Soteriologi). Pengajaran mengenai keselamatan merupakan doktrin yang sangat penting dalam Alkitab dan bagi gereja sepanjang zaman sampai pada masa kini karena menyangkut mengenai kekekalan manusia di hadapan Tuhan. Alkitab dengan jelas telah menegaskan mengenai eksistensi manusia yang berdosa secara sifat dasar (natur) maupun aktual, realitas anugerah Allah yang telah dinyatakan melalui Pribadi dan Karya pendamaian Tuhan Yesus Kristus di kayu salib serta pentingnya iman sebagai sarana menerima keselamatan. Seperti halnya, aspek-aspek keselamatan lainnya maka pengudusan (sanctification) merupakan karya anugerah Allah yang perlu ditekankan oleh pengajaran dan pemberitaan gereja dewasa ini di tengah-tengah arus religiuisme, spiritualisme dan ritualisme yang menekankan kepada aspek manusia yang menentukan perkenanan Allah. Dalam gereja masa kini juga pengaruh dari pengajaran Pelagianisme maupun Semi Pelagianisme yang menekankan "perbuatan baik, pekerjaan dan kekudusan pribadi manusia" yang membuat manusia diselamatkan harus dijawab oleh pengajaran teologi Reformed mengenai karya anugerah keselamatan dari Allah (Sola Gracia/Grace Alone) yang alkitabiah dan tetap relevan.

Kedua, munculnya sikap pesimisme dunia terhadap orang-orang percaya (kekristenan/gereja) saat ini yang memperlihatkan tidak sepadannya kehidupan orang percaya dengan nilai-nilai Alkitab. Bukankah orang-orang percaya berdasarkan Alkitab disebut sebagai "orang kudus" sesuai dengan esensi pengudusan definitif mereka? Namun kelihatannya orang-orang percaya masih mengulangi dosa-dosa dan kesalahan-kesalahan yang sama di masa lalu setelah menerima keselamatan. Bukankah setiap orang percaya telah diangkat menjadi anak-anak Allah dan Roh Kudus telah berdiam di dalam kehidupannya? Karena itu, doktrin pengudusan orang percaya harus lebih ditekankan lagi dewasa ini. Penekanan terhadap tujuan Allah dalam memilih orangorang di dalam Kristus adalah supaya mereka kudus dan supaya mereka 
menyatakan gambar kudus dari Yesus Kristus yang terwujud dalam kehidupan sehari-hari. Gereja dewasa ini harus lebih menekankan pengajaran orang-orang percaya yang telah dibenarkan oleh Allah di dalam Kristus haruslan menjalani hidup dengan cara yang berbeda (terpisah) dari mereka yang lain. Atas dasar pembenaran (justification) dalam kehidupannya maka ia harus hidup untuk menyatakan pembenaran yang telah ia terima dengan kehidupan di dalam pengudusan. ${ }^{53}$

Ketiga, doktrin pengudusan (sanctification) dewasa ini sangat relevan untuk ditekankan, diajarkan dan diterapkan dalam situasi dunia yang polusi dosa semakin memuncak. Tingkat kriminalitas seperti pembunuhan, terorisme, perampokan, pemusnahan masal manusia semakin menggila. Korupsi, kolusi, dan nepotisme yang bukan saja muncul dalam kancah politik tetapi telah masuk dalam dunia pelayanan yang makin mewabah. Kejahatan seksual seperti perdagangan anak dan perempuan, pelacuran, perkosaan, sodomi serta mewabahnya manusia yang pro dan hidup sebagai LGBT (Lesbian, Gay, Bisexual dan Transgender). Belum lagi dengan bergugurnya hamba-hamba Tuhan selebrity karena harta, takhta dan seksualitas. Hal ini seharusnya menyebabkan gereja semakin giat untuk menekankan pengajaran mengenai pengudusan yang Alkitabiah. Pengudusan dewasa ini juga menyangkut pelayanan atau misi gereja untuk melayani orang-orang yang belum mengenal Tuhan Yesus Kristus dengan berita Injil serta melayani orang-orang miskin dan terpinggirkan dengan menegakkan kebenaran dan keadilan Allah. Pada akhirnya doktrin pengudusan yang berangkat dari karya anugerah Roh Kudus dalam diri orang percaya secara pribadi harus terus mengarah kepada upaya transformasi masyarakat dengan nilai-nilai Injil Kerajaan Allah. Dengan demikian doktrin pengudusan tidak sekadar people oriented melainkan life oriented. Sehingga akan terwujud apa yang menjadi visi Yohanes Calvin, pada waktu beliau menyatakan bahwa alam semesta ini theatrum gloride Dei (panggung kemuliaan Allah). ${ }^{54}$

\section{Kepustakaan}

Arrington, French L. Jaminan Keselamatan Kekal Yang Tak Bersyarat. Jakarta: Light Publishing, 2015.

Becker, Dieter. Pedoman Dogmatika. Jakarta: BPK Gunung Mulia, 2012.

\footnotetext{
${ }^{53}$ Ebenhaizer Nuban Timo, 326.

${ }^{54}$ Eka Darmaputera, "Pelayanan Holistik" dalam Membangun Manusia Indonesia Seutuhnya di Pedesaan (Yogyakarta: Penerbit Andi dan Yayasan PESAT, 1994), 48.
} 
Aritonang, Jan Sihar. Garis Besar Sejarah Reformasi. Bandung: Jurnal Info Media, 2007.

Berkhof, Louis. Teologi Sistematika Volume 4. Surabaya: Momentum, 2000.

Boersema, Jan A. Ed. Berteologi Abad XXI. Jakarta: Literatur Perkantas, 2015.

De Jonge, Christiaan. Gereja Mencari Jawab; Kapita Selekta Sejarah Gereja. Jakarta: BPK Gunung Mulia, 2000.

Hadiwiyono, Harun. Iman Kristen. Jakarta: PT BPK Gunung Mulia, 2012.

Hoekoema, Anthony. Diselamatkan Oleh Anugerah. Surabaya: Momentum, 2000.

Lohse, Bernhard. Pengantar Sejarah Dogma Kristen. Jakarta: PT BPK Gunung Mulia, 2011.

Matalu, Muriwali Yanto. Dogmatika Kristen Dari Perspektif Reformed . Malang: Gerakan Kebangunan Kristen Reformed, 2015.

McKim, Donald K.. Encyclopedia of The Reformed Faith. Louisville, Kentucky: Westminer/John Knox Press, 1992.

Membangun Manusia Indonesia Seutuhnya di Pedesaan. Yogyakarta: Penerbit ANDI dan Yayasan PESAT, 1994.

Murray, John. Penggenapan dan Penerapan Penebusan. Surabaya: Penerbit Momentum, 2010.

Nuban Timo, Ebenhaizer. Allah Menahan Diri Tetapi Pantang Berdiam Diri: Satu Upaya Berdogmatika Kontenstual di Indonesia. Jakarta: PT BPK Gunung Mulia, 2015.

Soedarmo. Ikhtisar Dogmatika. Jakarta: PT BPK Gunung Mulia, 2013.

Sproul, R. C. Hanya Melalui Iman. Bandung: Penerbit Mitra Pustaka, 2004.

Sproul, R. C. Kebenaran-Kebenaran Dasar Iman Kristen. Malang: Literatur SAAT, 2005.

Susabda, Yakub. Seri Pengantar Teologi Modern I. Jakarta: Lembaga Reformed Injili Indonesia, 1990. 